\title{
Weed Community in a Raw Sugarcane Renovation ARea SubmitTed to Different SoIl Managements ${ }^{1}$
}

\author{
Comunidade Infestante e Área de Reforma de Cana Crua Submetida a Diferentes Manejos
}

\author{
SOARES, M.B.B. ${ }^{2}$, BIANCO, S. ${ }^{3}$, FINOTO, E.L. ${ }^{2}$, BOLONHEZI, D. ${ }^{4}$, ALBUQUERQUE, J.A.A. ${ }^{5}$, and \\ SILVA, A.A. ${ }^{6}$
}

\begin{abstract}
The objective of this study was to evaluate the weed community in a raw sugarcane renovation area with three soil managements and peanut sowing in succession. The experiment was conducted during the $2007 / 08$ season on a raw sugarcane area harvested without prior burning in the last five cuts. A randomized block design with treatments arranged in a split plot and arranged in four replications was used. The main treatments consisted of three cropping systems: conventional tillage, minimum tillage and direct planting, and subplots consisted in the absence (resting) or presence of crop rotation with peanuts. After 135 days from planting peanuts and 180 days of sugarcane harvest, the number of weeds $\mathrm{m}^{-2}$ was counted and the shoot dry biomass of the weeds collected was determined. The data were interpreted by analysis of variance and the means were compared by Tukey's test at $5 \%$ probability so that phytosociological indices $a, b, c$ e $d$ were calculated. The use of soil conservation tillage and peanut in rotation with sugarcane in the renovation areas is effective in controlling weeds and suppression of weed species difficult to control like Cyperus rotundus, Commelina bengalensis, Urochloa plantaginea, and Digitaria nuda.
\end{abstract}

Keywords: Arachis hypogaea, Saccharum spp., direct planting, minimum tillage, fallow, phytosociology.

RESUMO - Acredita-se ser possivel reduzir o custo com o controle de plantas daninhas em áreas de reforma de cana crua adotando-se sistemas de manejos adequados. Objetivou-se com este trabalho avaliar a comunidade infestante em área de reforma de cana crua submetida a diferentes manejos. Nesta pesquisa, utilizando-se uma área de um canavial colhido sem queima prévia, nos últimos cinco cortes foram avaliados três sistemas de cultivo: convencional, mínimo e plantio direto, associados ao pousio e cultivo do amendoim. Após 135 dias da semeadura do amendoim e 180 dias da colheita da cana-de-açúcar, foi feita a contagem do número de plantas daninhas por meetro quadrado e da matéria seca da parte aérea das plantas daninhas coletadas. Todos os dados obtidos foram analisados estatisticamente. Para interpretação dos resultados, utilizou-se o teste de Tukey a 5\% de probabilidade e valores dos indices fitossociológicos $a, b$, c e d calculados. Conclui-se que a utilização do sistema de plantio direto associado ao cultivo do amendoim em rotação com a cana-de-açúcar em áreas de cana crua favorece o controle e a supressão de espécies de plantas daninhas de dificil controle, como Cyperus rotundus, Commelina benghalensis, Urochloa plantaginea $e$ Digitaria nuda.

Palavras-chave: Arachis hypogaea, Saccharum spp., plantio direto, cultivo mínimo, pousio, fitossociologia.

Recebido para publicação em 1.6.2015 e aprovado em 6.10.2015.

Agência Paulista de Tecnologia do Agronegócio (APTA), Pindorama, SP, Brasil, < beatriz@apta.sp.gov.br >; ${ }^{3}$ Universidade Estadual Paulista, Júlio de Mesquita Filho (UNESP), Jaboticabal, SP, Brasil; ${ }^{4}$ Agência Paulista de Tecnologia do Agronegócio (APTA), Ribeirão Preto, SP, Brasil; ${ }^{5}$ Universidade Federal de Roraima (UFRR), Boa Vista, RR, Brasil; ${ }^{6}$ Universidade Federal de Viçosa (UFV), Viçosa, MG, Brasil. 


\section{INTRODUCTION}

The process of sugarcane harvest is moving from traditional burning to mechanized harvesting, either by law enforcement or environmental awareness. The adoption of this system has resulted in significant changes in farming techniques, such as using larger spacing and deposition of straw on the ground, which directly influence weed occurrence and management.

The deposition of sugarcane stover on the ground provides changes of weed populations, favoring species with greater germination capacity under a thick straw cover (Ferreira et al., 2010). Research conducted by Soares et al. (2011) indicates that the germination and establishment of species with little reserves stored in the seed are adversely affected by the physical and/or allelopathic effects imposed by the layer of sugarcane straw. Thus, the community studies in raw sugarcane renovation areas submitted to different tillages could generate information of great interest to establish integrated management programs of weeds in sugarcane plantations, which could result in reduced herbicide use, lower production cost and lower environmental impact.

However, while raw sugarcane harvest presents agronomic benefits, a lot of waste left on the surface and the intense mechanization of the area may reduce the sugarcane plantation longevity (Soares et al., 2012). Sugarcane fields renovation is performed on average after five sugarcane crops, and in most cases these areas remain in fallow during the period between the sugarcane harvest and the implementation of the new sugarcane field. However, the use of plants in nutrient recycling and maintenance of soil fertility, associated with direct planting and minimum tillage techniques, are options for obtaining production efficiency and soil and water conservation (Ambrosano et al., 1999). Among the benefits of the use of crop rotation, increased crop productivity is highlighted, besides the benefits of controlling pests, diseases and weeds, and improving fertility and physical characteristics of the soil (Christoffoleti et al., 2007).
However, the soil management system and the choice of crop that will be used in rotation are of great importance in the integrated management of weeds in agricultural areas. The preceding crop and soil management system influence the composition of the plant community (Zimdahl; 1993; Cardina et al., 2002).

Results from research by Silva \& Beltrão (1998), Martins (2011), Cruz \& Magalhães (2013), Barbosa et al. (2014) and Silva \& Fernandes (2014) indicate that sugarcane with peanut (also known as groundnut (Arachis hypogaea)) crop rotation is economically and environmentally viable. In the Brazilian state of São Paulo, sugarcane producers have adopted for decades the management of peanuts in intercropping with sugarcane in the off-season period, giving various benefits to the main crop, such as improving soil fertility, nematode control and aggregation of additional income from peanut crops (Melo Filho \& Santos, 2010), increased productivity of stalks (Aleoni \& Beauclair, 1995), decrease in the nematodes population occurring in sugarcane (Ambrosano et al., 2011), better soil conservation due to soil cover in the heavy rainfall season (Volk et al., 2004) and nutrient cycling (Feitosa et al., 1993).

In this work were determined the phytosociological indices values of a weed community present in a sugarcane plantation area harvested without burning the last five cuts, followed by three farming systems: conventional tillage, minimum tillage and direct planting, associated with fallow and peanuts cultivation.

\section{MATERIALS AND METHODS}

The experiment was conducted in the Brazilian municipality of Novais, SP (20'59' 32'" south latitude, 48 55' 07' west longitude and average altitude $555 \mathrm{~m}$ ) in a sugarcane field belonging to the plant Usina Cerradinho on an eutroferric red-yellow acrisol soil.

The last sugarcane harvest was done in the first fortnight of July. After harvesting, the amount of sugarcane straw was calculated at $14 \mathrm{t} \mathrm{ha}^{-1}$ using random samples of $1 \mathrm{~m}^{2}$ in the area. After defining the plots for renovation, 
the areas were desiccated with glyphosate at a dose of $2,160 \mathrm{~g} \mathrm{ha}^{-1}$. The survey was carried out in this area, which consisted in the evaluation of three cropping systems (conventional tillage, minimum tillage and direct planting), associated with the cultivation of peanuts and fallow. Each plot was $8.0 \mathrm{~m}$ wide by $20 \mathrm{~m}$ long, and the whole plot was considered as floor area for randomly throwing the leaked sample frame $\left(1 \mathrm{~m}^{2}\right)$. Conventional tillage (CT) was established by the use of harrow + moldboard plow + graders; minimum tillage (MT) was established by the use of vegetation chemical desiccation with glyphosate + plow levee with clod breaker (ASTMATIC 450); and direct planting (DP) was established by the use of glyphosate desiccation followed by planting without soil disturbance. Secondary treatments were formed as follows: peanut cv. IAC-886 and fallow.

The plots in fallow were kept with spontaneous vegetation without mowing or herbicide use. The creeping peanuts crop of cultivar Runner IAC 886 (creeping cultivar of high-yield potential; 125 day cycle) was sown in a $0.90 \mathrm{~m}$ spacing between rows in eight crop rows with planting density of 18 seeds per linear meter, with a seeder with eight rows and a double mismatched disk system in the fertilizer distribution. The fertilization was performed according to the analyses results and the technical recommendations. While conducting the test, chemical weed control was used for peanuts, employing imazapic in the dose recommended by the manufacturer: $140 \mathrm{~g}$ of commercial product per hectare (98 $\mathrm{g} \mathrm{ha}^{-1}$ ) in preemergence of the peanut culture, i.e., 135 days before evaluation of the weeds.

Ten days after the peanuts harvest, two points of $1.0 \mathrm{~m}^{2}$ per plot were sampled at random for weed evaluation. In each sample, the plants were identified; then their aerial parts were cut, placed in paper bags and sent to the laboratory where they were dried in a forced air circulation oven and kept at $60{ }^{\circ} \mathrm{C}$ for 72 hours for later weighing on a precision scale $(001 \mathrm{~g})$. Data were tabulated and statistically interpreted using analysis of variance, and the means were compared by the Tukey's test $(\mathrm{p}<0.05)$.

Number of plants, dry matter and specific frequency data were used for determination of the phytosociological indices: relative density - RDe; relative dominance - RDo; relative frequency - RFr; importance value index - IVI; and relative importance value index - RIVI (Braun-Blanquet, 1979). Then the calculation of the similarity index (SI) was performed in the two areas studied (Sorensen, 1972).

\section{RESULTS AND DISCUSSION}

Twenty-two weed species were found in the area, divided into 12 botanical families (Table 1). The families with the highest number of species found in the area were Asteraceae, Amaranthaceae and Poaceae. Direct planting showed higher species richness (13), followed by minimum tillage (11) and conventional tillage (8); both fallow as peanut crop showed 15 species.

When evaluating the number of weeds in the area (Table 2), there was a significant interaction between the primary (soil management) and secondary (presence or absence of peanut culture) treatments. The minimum tillage of the area in fallow promoted higher weed infestation per unit of area than the other treatments, but the number of weeds of this crop significantly decreases when the fallow is exchanged for rotation with peanuts. As for the other soil managements, there is no difference between fallow and peanut crop.

In general, the use of direct planting promotes a significant reduction (approximately 40\%) in the number of weeds, both in areas in fallow as in those of peanut cultivation. The incidence of weeds in sugarcane cultivated in conventional tillage is up to $531 \%$ higher than the incidence in direct planting areas, accounting for $27 \%$ decrease in crop productivity (Duarte Júnior et al., 2009).

For weeds dry matter (Table 3), as well as the number of weeds, there was a significant interaction between the primary and secondary treatments. Thus, in the areas of conventional tillage, when left in fallow, the weeds dry matter was higher than in the other treatments. Adopting minimum tillage in areas in fallow has significantly reduced the weeds dry matter compared to the 
Table 1 - List of species found in the area, botanical families, common names and their respective experimental $\mathrm{EPPO}^{1 /}$ codes. Novais, SP, 2008

\begin{tabular}{|c|c|c|c|}
\hline Family & Scientific name & Common name & EPPO $\operatorname{code}^{1 /}$ \\
\hline \multirow{3}{*}{ Amaranthaceae } & Amaranthus deflexus L. & $\begin{array}{l}\text { Large-fruit amaranth, low } \\
\text { amaranth, or Argentina amaranth. }\end{array}$ & AMADE \\
\hline & $\begin{array}{l}\text { Dysphania ambrosioides, formerly Chenopodium } \\
\text { ambrosioides }\end{array}$ & $\begin{array}{l}\text { Wormseed, Jesuit's tea, Mexican- } \\
\text { tea, paico, epazote, or herba sancti } \\
\text { Mariæ }\end{array}$ & CHEAP \\
\hline & Gomphrena globosa L. & Globe amaranth or bachelor button & GOMGL \\
\hline \multirow{8}{*}{ Asteraceae } & Acanthospermum hispidum D.C. & $\begin{array}{l}\text { Bristly starbur, goat's head, hispid } \\
\text { starburr, or starbur }\end{array}$ & ACNHI \\
\hline & Ageratum conyzoides $\mathrm{L}$. & $\begin{array}{l}\text { Billygoat-weed, chick weed, } \\
\text { goatweed, whiteweed }\end{array}$ & AGECO \\
\hline & Bidens pilosa $\mathrm{L}$. & $\begin{array}{l}\text { Black-jack, beggarticks, cobbler's } \\
\text { pegs, or Spanish needle }\end{array}$ & BIDPI \\
\hline & Conyza canadensis (L.) Cronquist & Horseweed & ERICA \\
\hline & Emilia sonchifolia Nicolson & Florida tasselflower & EMISO \\
\hline & Galinsoga parvoflora $\mathrm{Cav}$ & Gallant soldier or potato weed & GASPA \\
\hline & Parthenium hysterophorus $\mathrm{L}$. & $\begin{array}{l}\text { Tropical Mexican clover, Brazilian } \\
\text { calla-lily, white-eye, or Brazil } \\
\text { pusley }\end{array}$ & PYNHY \\
\hline & Tridax procumbens $\mathrm{L}$. & Coat buttons or tridax daisy & TRQPR \\
\hline Commelinaceae & Commelina benghalensis $\mathrm{L}$ & Benghal dayflower & COMBE \\
\hline Convolvulaceae & Ipomoea nil (L.) Roth & Heart-leaved morning glory & IPONI \\
\hline Cyperaceae & Cyperus rotundus $\mathrm{L}$ & Purple nutsedge & CYPRO \\
\hline Fabaceae & Aeschynomene rudis Benth. & Zigzag jointvetch & AESSH \\
\hline Malvaceae & Sida rhombifolia $\mathrm{L}$. & $\begin{array}{l}\text { Arrowleaf sida, rhombus-leaved } \\
\text { sida, Paddy's lucerne, jelly leaf, or } \\
\text { also somewhat confusingly as } \\
\text { Cuban jute, Queensland hemp, and } \\
\text { Indian hemp }\end{array}$ & SIDRH \\
\hline Phyllanthaceae & Phyllanthus tenellus Roxb. & Leafflower & PYLTE \\
\hline \multirow{2}{*}{ Poaceae } & Urochloa plantaginea (Link) R. D. Webster & Plantain signalgrass & BRAPL \\
\hline & Digitaria nuda Schumach. & Crabgrass, finger-grass, or fonio & DIGNU \\
\hline Portulacaceae & Portulaca oleracea L. & $\begin{array}{l}\text { Purslane, also known as verdolaga, } \\
\text { pigweed, little hogweed, red root, } \\
\text { pursley, and moss rose }\end{array}$ & POROL \\
\hline Rubiaceae & Richardia brasiliensis Gomes & $\begin{array}{l}\text { Tropical Mexican clover, Brazilian } \\
\text { calla-lily, white-eye, or Brazil } \\
\text { pusley }\end{array}$ & RCHBR \\
\hline Solanaceae & Solanum americanum Mill. & $\begin{array}{l}\text { American nightshade or glossy } \\
\text { nightshade }\end{array}$ & SOLAM \\
\hline
\end{tabular}

1/ EPPO code: also known as Bayer code, is an encoding system used by the European and Mediterranean Plant Protection Organization (EPPO) to designate plants, pests and pathogens that are important for agriculture, 2014. 
Table 2 - Weeds number in the three soil management systems for fallow and peanut sowing in succession. Novais, SP, 2008

\begin{tabular}{|l|c|c|c|}
\hline \multirow{2}{*}{} & \multicolumn{2}{|c|}{ Number of plants ${ }^{1 /}$} & \multirow{2}{*}{ F-test } \\
\cline { 2 - 3 } & Fallow & Peanut & \\
\hline Conventional tillage & $82.00 \mathrm{Ba}$ & $81.00 \mathrm{Aa}$ & \multirow{3}{*}{$37.68 * *$} \\
\hline Minimum tillage & $98.00 \mathrm{Aa}$ & $72.00 \mathrm{Ab}$ & \\
\hline Direct planting & $49.00 \mathrm{Ca}$ & $48.00 \mathrm{Ba}$ & \\
\hline F-test & \multicolumn{2}{|c|}{$21.0942 * *$} \\
\hline Interaction & \multicolumn{2}{|c|}{$16.8161 * *$} \\
\hline CV plot (\%) & \multicolumn{2}{|c|}{12.94829} \\
\hline CV subplot (\%) & \multicolumn{2}{|c|}{6.94567} \\
\hline
\end{tabular}

1/ Means followed by the same letters, uppercase in the column and lowercase in the row, do not differ significantly by Tukey's test $(\mathrm{p}<0.05)$; ** Significant at $1 \%$ probability by the $\mathrm{F}$ test; ${ }^{\text {ns }}$ Nonsignificant.

conventional tillage system (15.4\%); when the area remains in fallow, the use of direct planting reduces by $62 \%$ and $55 \%$ the plants matter compared to conventional tillage and minimum tillage, respectively. As soil management becomes more conservationist, the importance of crop rotation with peanuts decreases. This culture reduces the dry matter of the weed community in conventional tillage and minimum tillage $(45 \%$ and $28 \%$, respectively), demonstrating the importance of crop rotation in management systems where the stover is incorporated into the soil, although in different degrees.

It is not possible to assign the infestation reduction in management areas with the incorporation of the stover and peanut predecessor cultivation only to the effects of physical suppression caused by the plant itself, because it is necessary to consider that the peanut crop was treated with imazapic in preemergence, whose half-life in soil $\left(\mathrm{t}^{1} / 2\right)$ is greater than 180 days, showing residual activity in the soil, which may give it herbicidal action on the weed seedbeds.

Figures 1,2 and 3 show the phytosociological parameters - relative frequency $(\mathrm{RFr})$, relative density (RDe), relative dominance (RDo), importance value index (IVI) and relative importance value index (RIVI) of the species found in the soil management systems for the area in fallow and peanut cultivation.
Table 3 - Weeds dry matter in the three soil management systems for fallow and peanut sowing in succession. Novais, SP, 2008

\begin{tabular}{|l|c|c|c|}
\hline \multirow{2}{*}{} & \multicolumn{2}{|c|}{ Dry matter ${ }^{1 /}\left(\mathrm{g} . \mathrm{m}^{-2}\right)$} & \multirow{2}{*}{ F-test } \\
\cline { 2 - 3 } & Fallow & Peanut & \\
\hline Conventional tillage & $810.00 \mathrm{Aa}$ & $430.00 \mathrm{Ab}$ & \multirow{2}{*}{$52.81 * *$} \\
\hline Minimum tillage & $685.00 \mathrm{Ba}$ & $495.00 \mathrm{Ab}$ & \\
\hline Direct planting & $305.00 \mathrm{Ca}$ & $240.00 \mathrm{Ba}$ & \\
\hline F-test & \multicolumn{2}{|c|}{$85.3386 * *$} \\
\hline Interaction & \multicolumn{3}{|c|}{$15.9735^{* *}$} \\
\hline CV plot (\%) & \multicolumn{3}{|c|}{15.1658} \\
\hline CV subplot (\%) & \multicolumn{2}{|c|}{11.3575} \\
\hline
\end{tabular}

${ }^{1 /}$ Means followed by the same letters, uppercase in the column and lowercase in the row, do not differ significantly by Tukey's test $(\mathrm{p}<0.05) ; * *$ Significant at $1 \%$ probability by the $\mathrm{F}$ test; ${ }^{\text {ns }}$ Nonsignificant.

Cyperus rotundus assumes greater importance among the weeds in all arrangements of soil management system and culture in succession, reaching a relative importance value index (RIVI) of $54.1 \%$ in areas of fallow and conventional tillage; however, the conservationist soil management and crop rotation minimize the problems with the species, reducing its importance (RIVI at $23.5 \%$ ) in direct planting fields with crop rotation with peanuts (Figure 1).

In conventional tillage areas there was lower species richness. Of the seven species found in the areas of fallow, five can be considered difficult to control, such as Cyperus rotundus, Commelina benghalensis, Sida rhombifolia, Digitaria nuda, and Urochloa plantaginea, whose combined RIVIs are equivalent to $89 \%$ of the area infestation. Purple nutsedge (C. rotundus) was the most important species in the area, with a relative importance value index (RIVI) equivalent to $54 \%$ of the total, with the highest relative frequency, the highest relative density and the highest relative dominance: $33.3 \%, 76.3 \%$ and $51,9 \%$, respectively.

In the conventional tillage areas, although in rotation with peanut crops, only five species were found, of which only purple nutsedge and Benghal dayflower (Commelina benghalensis), with RIVI of $52 \%$ and $35 \%$, respectively, can be considered problematic. Both species were present in all samples and obtained RFr of 


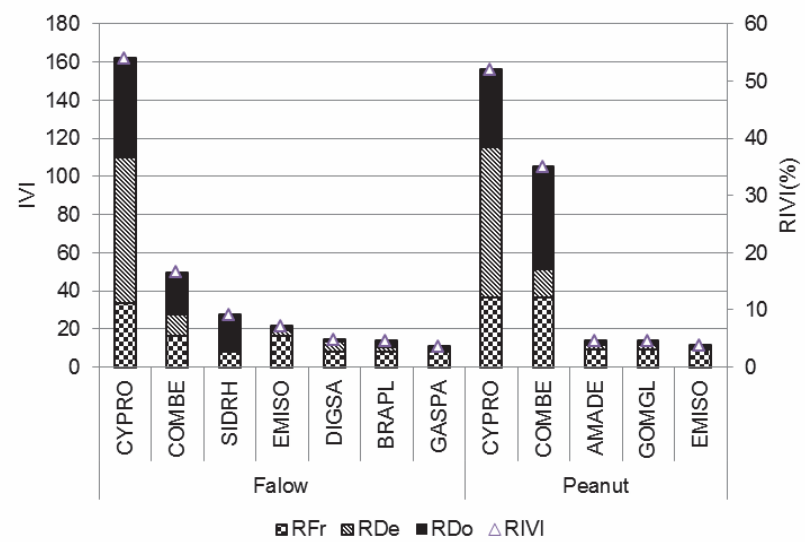

Figure 1 - Phytosociological parameters RFr, RDe, RDo, IVI and RIVI for the major weed species in areas with conventional tillage in fallow or peanuts in succession. Novais, SP, 2008.

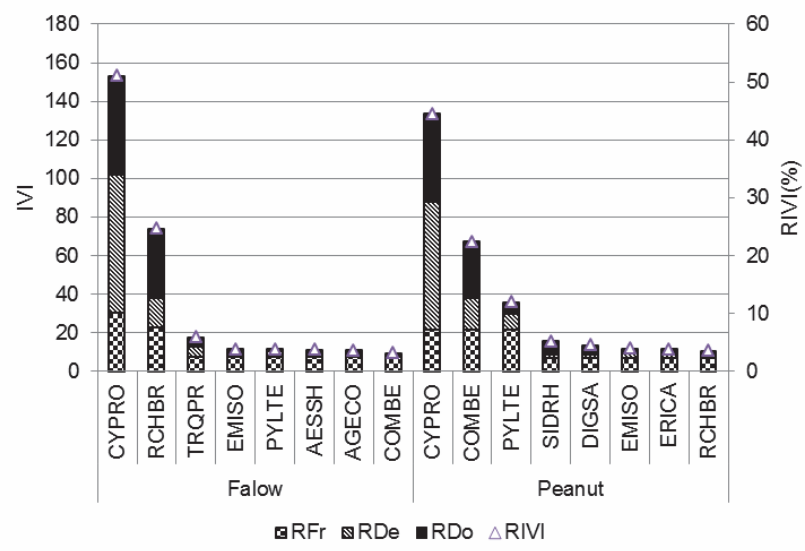

Figure 2 - Phytosociological parameters RFr, RDe, RDo, IVI and RIVI for the major weed species in areas with minimum tillage in fallow or peanuts in succession. Novais, SP, 2008.

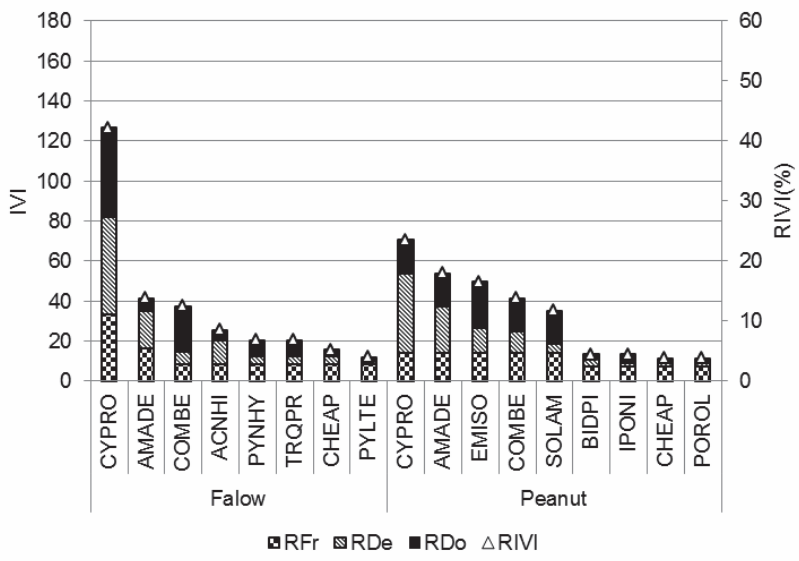

Figure 3 - Phytosociological parameters RFr, RDe, RDo, IVI and RIVI for the major weed species in areas with direct planting in fallow or peanuts in succession. Novais, SP, 2008 .
36.4\%; purple nutsedge had the highest RDe (79\%), and Benghal dayflower stood out for its dominance (53.85\%).

For areas where the soil management adopted was minimum tillage, the number of species increased compared to conventional tillage, rising to eight in both the fallow as in the peanuts fields.

In areas of fallow, the main species remained purple nutsedge, with an RIVI of $51.1 \%$, followed by tropical Mexican clover (Brazilian calla-lily, white-eye, or Brazil pusley) (R. brasiliensis), with an RIVI of $24,7 \%$. The highest relative frequency, relative density and relative dominance were obtained with purple nutsedge, with $30.8 \%, 71.4 \%$ and $51 \%$, respectively. In the areas of crop rotation and minimum tillage, purple nutsedge remained the main weed, followed by Benghal dayflower and leafflower ( $P$. tenellus), with an RIVI of $44.5 \%, 22.5 \%$ and $11,9 \%$, respectively. The three species achieved the highest relative frequencies $(21.4 \%)$. Purple nutsedge showed the highest relative density and relative dominance $(66.7 \%$ and $45.5 \%)$, followed by Benghal dayflower (16.7\% and 29.3\%) and leafflower $(8.3 \%$ and $6.1 \%)$.

In direct planting areas, the largest number of weed species of the evaluated soil managements was found, being eight species for the area in fallow and nine for the area with crop rotation.

Purple nutsedge was the most important species in the areas of direct planting kept in fallow, with an RIVI of $42.2 \%$ with higher relative frequency $(33.3 \%)$, higher relative density (49\%) and relative dominance $(44.2 \%)$, followed by $A$. deflexus (large-fruit amaranth, low amaranth, or Argentina amaranth.) and Benghal dayflower. Also noteworthy is Starburr (A. hispidum), with a relative density of $12.2 \%$.

Although it continues to be the species of a higher relative importance value index, purple nutsedge (RIVI $=23.5 \%$ ) has lost its importance in relation to other species. Other important species in the direct planting area were large-fruit amaranth, Florida tasselflower (E. fosbergii), Benghal dayflower and American black nightshade (or glossy nightshade) (S. americanum), all with an RIVI higher than $10 \%$. 
As soil management becomes more conservationist, the purple nutsedge RIVI decreases. Soares et al. (2012) have found similar results in work comparing soil management and crop rotation with green manures. The decrease of the nutsedge importance when peanuts are grown in succession to sugarcane may be due both to the dampening provided by the vegetation cover as the residual effect of imazapic applied in peanut crops, for the transposition of imazapic through sugarcane straw is highly significant (Ferreira et al., 2010).

C. benghalensis was also a very problematic species in different soil managements, especially in conventional tillage. With the introduction of peanut cultivation and the loss of importance of $C$. rotundus, this species has gained importance thanks to its high dry matter and the difficulty of control when the plants are mature and large.

The poaceae (grass) lost importance and virtually disappeared as the soil management became more conservationist. In the conventional tillage area in fallow were found plants of $U$. plantaginea and $D$. nuda, which together reached a relative importance value index of $9.5 \%$. In minimum tillage and direct planting plots, plants of this family were not found. Therefore, the presence of ground cover affects the development of grasses. For Monquero et al. (2008), sugarcane straw control was highly effective in the case of grasses from seeds, and infestations of these species occur where there is irregularity in straw distribution.

Both sugarcane straw of the most conservationist managements as peanut crops in succession produced the same effect on species diversity: species that were not competitive enough to grow in the presence of the two species of greatest importance of the area either by the high density of C. rotundus or the high dominance of $C$. benghalensis; species such as $A$. deflexus, $R$. brasiliensis and $T$. procumbens had their high relative importance; and species such as $S$. americanum, C. ambrosioides, P. oleracea and $I$. nil developed, changing the weeds profile. Almeida (1985) noted that in conventional tillage and minimum tillage there was predominance of species considered problematic, whereas in the cultivation without revolving the land the weed community is more balanced.

I. nil and $P$. oleracea were found in the direct planting plots and were not found in other soil managements. This behavior can be explained by the fact that these species have seeds considered as having a negative photoblastic behavior, that is, with its germination increased in the absence of light (Orzari et al., 2013).

Tables 4 and 5 show the similarity indices comparing soil management and cultures. Comparing fallow with crop rotation, these were more similar when the soil management used was the minimum tillage (62.5\%) and less similar under direct planting (Table 4). But when comparing the soil managements when the plot remained in fallow, the most similar ones were minimum tillage and direct planting, and the least similar ones were direct planting and conventional tillage. For plots in rotation with peanut crops, the most similar managements were conventional tillage and direct planting, and the less similar ones were minimum tillage and direct planting (Table 5).

The use of a conservationist soil management and peanuts in rotation with sugarcane in the renovation fields of

Table 4 - Index of similarity between weeds infestation in a fallow area and rotation with peanuts under different soil management systems. Novais, SP, 2008

\begin{tabular}{|l|c|}
\hline \multicolumn{1}{|c|}{ Soil tillage } & $\mathrm{S}(\mathrm{PxA})^{1 /}$ \\
\hline Conventional tillage & $54.5 \%$ \\
\hline Minimum tillage & $62.5 \%$ \\
\hline Direct planting & $47.1 \%$ \\
\hline
\end{tabular}

${ }^{1 /} \mathrm{P}$, fallow; $\mathrm{A}$, rotation with peanuts.

Table 5 - Index of similarity among the different soil management systems when in fallow or rotation with peanuts. Novais, SP, 2008

\begin{tabular}{|l|c|c|c|}
\hline Cultivation & $\mathrm{S}(\mathrm{PCxCM})^{\frac{1}{}}$ & $\mathrm{~S}(\mathrm{CMxPD})$ & $\mathrm{S}(\mathrm{PCxPD})$ \\
\hline Fallow & $42.9 \%$ & $50.0 \%$ & $28.6 \%$ \\
\hline Peanut & $46.2 \%$ & $35.3 \%$ & $57.1 \%$ \\
\hline
\end{tabular}

1/ CT, conventional tillage; MT, minimum tillage; DP, direct planting.

Planta Daninha, Viçosa-MG, v. 34, n. 1, p. 91-98, 2016 
sugarcane harvested raw proved beneficial in controlling weed populations, particularly species difficult to control, such as Cyperus rotundus, Commelina bengalensis, Urochloa plantaginea and Digitaria nuda.

\section{LITERATURE CITED}

ALLEONI L. R. F.; BEAUCLAIR, E. G. F. Cana-de-açúcar cultivada após milho e amendoim, com diferentes concentrações de adubo. Sci. Agríc., v. 53, n. 3, p. 409-415, 1995.

ALMEIDA, F. S. Influência da cobertura morta do plantio direto na biologia do solo. Atualização em plantio direto. Campinas: Fundação Cargill, 1985. p. 103-144.

AMBROSANO, E. J. et al. Productivity of sugarcane after previous legumes crop. Bragantia, v. 70, n. 4, p. 810-818, 2011.

AMBROSANO, E. J. et al. Leguminosas: alternativas para produção ecológica de grãos em diferentes regiões agroecológicas do Estado de São Paulo. In: AMBROSANO, E. J. Agricultura ecológica. Guaíba: Agropecuária, 1999. p. 161-178.

BARBOSA, R. M.; HOMEM, B. F. M.; TARSITANO, M. A. A. Custo de produção e lucratividade da cultura do amendoim no município de Jaboticabal, São Paulo. Ceres, v. 61, n. 4 , p. $475-481,2014$.

BRAUN-BLANQUET, J. Fitossociologia: bases para el estudio de las comunidades vegetales. Madrid: H. Blume, 1979. 820 p.

CARDINA, J. et al. Crop rotation and tillage system effects on weed seedbanks. Weed Sci., v. 50, n. 4, p. 448-460, 2002.

CHRISTOFFOLETI, P. J. et al. Conservation of natural resources in Brazilian agriculture: implications on weed biology and management. Crop Protec., v. 26, p. 383-389, 2007.

CRUZ, M. R. O.; MAGALHÃES, M. M. Rotação de culturas e efeito sobre os custos na reforma de canavial na região da Alta Paulista. Periódico Eletrônico Fórum Ambiental da Alta Paulista, online, v. 9, n. 7, 2013. Disponível em: $<$ http://amigosdanatureza.org.br/publicacoes/ index.php/forum_ambiental/article/view/549/574>. Acesso em: 10 jan. 2015.

DUARTE JÚNIOR, J. B. et al. Dinâmica de populações de plantas daninhas na cana-de-açúcar em sistema de plantio direto e convencional. Semina: Ci. Agr., v. 30, n. 3, p. 595-612, 2009.
FEITOSA, C. T. et al. Avaliação do crescimento e da utilização de nutrientes pelo amendoim. Sci. Agríc., v. 50, n. 3, p. 427-437, 1993.

FERREIRA, E. A. et al. Manejo de plantas daninhas em canacrua. Planta Daninha, v. 28, n. 4, p. 915-925, 2010.

MARTINS, R. Produção de amendoim e expansão da cana-deaçúcar na Alta Paulista, 1996-2010. Inf. Econ., v. 41, n. 6, 2011.

MELO FILHO, P. A.; SANTOS, R. C. A cultura do amendoim no nordeste: Situação atual e perspectivas. Acad Pernambucana Ci. Agron., v. 7, n. 1, p. 192-208, 2010.

MONQUERO, P. A. et al. Mapas de infestação de plantas daninhas em diferentes sistemas de colheita da cana-de-açúcar. Planta Daninha, v. 26, n. 1, p. 47-55, 2008.

ORZARI, I. et al. Germinação de espécies da família Convolvulaceae sob diferentes condições de luz, temperatura e profundidade de semeadura. Planta Daninha, v. 31, n. 1, p. 53-61, 2013.

SILVA, M. B.; BELTRÃO, N. E. M. Níveis populacionais e configurações de plantio na cultura do amendoim, em regime de sequeiro na mesorregião do agreste da Borborema do Estado da Paraíba. R. Oleag. Fibr., v. 4, n. 1, p. 23-34, 1998.

SILVA, R. P.; FERNANDES, C. Soil uses during the sugarcane fallow period: influence on soil chemical and physical properties and on sugarcane productivity. R. Bras. Ci. Solo, v. 38, n. 2, p. 575-584, 2014.

SOARES, M. B. B. et al. Fitossociologia de plantas daninhas sob diferentes sistemas de manejo de solo em áreas de reforma de cana crua. R.Agro@mbiente, v. 5, n. 3, p. 173-181, 2011.

SOARES, M. B. B. et al. Plantas daninhas em área de reforma de cana crua com diferentes manejos do solo e adubos verdes em sucessão. R.Agro@mbiente, v. 6, n. 1, p. 25-33, 2012.

SORENSEN, T. A. Method of establishing groups equal amplitude in plant society based on similarity of species content. In: ODUM, E.P. Ecologia. 3.ed. México: Interamericana, 1972. p. 341-405.

VOLK, L. B. S.; COGO, N. P.; STRECK, E. V. Erosão hídrica influenciada por condições físicas de superfície e subsuperficie do solo resultantes do seu manejo, na ausência de cobertura vegetal. R. Bras. Ci. Solo, v. 28, n. 4, p. 763-774, 2004.

ZIMDAHL, R. L. Fundamentals of weed science. London: Academic Press, 1993. 450 p. 